\title{
The Development of Effective English Teacher Improvement Program Based on a Case Study of English Teaching in Madrasah in Indonesia
}

\author{
Siti Nurul Azkiyah \\ UIN Syarif Hidayatullah, Jakarta, Indonesia \\ E-mail: azkiyah@uinjkt.ac.id
}

Received: 02-09-2016

Published: 01-03-2017
Accepted: 05-11-2016

doi:10.7575/aiac.ijalel.v.6n.2p.1
Advance Access Published: January 2017

URL: http://dx.doi.org/10.7575/aiac.ijalel.v.6n.2p.1

\begin{abstract}
Teachers play very important roles, yet not all teachers can teach well and hence it is important to develop a teacher improvement program. Therefore, this study observed teaching and learning process to understand current teacher instruction so that priorities could be easily set up. 11 English teachers participated in the study. The eight classroom factors of the dynamic model (Orientation, Structuring, Modeling, Application, Questioning, Assessment, Building Classroom as a Learning Environment, and Time Management) are used as the framework since they are theory-driven and have been empirically proven to lead to better student outcomes. The data on the teaching of reading were descriptively analyzed, the results of which show almost no teachers did orientation and structuring, which could serve as pre-reading activities. Modeling was not really provided and students were left not to have sufficient tasks, hence during reading activities were not well delivered. Questioning was practiced by teachers but was limited to "product" questions. Lastly, collaboration and competition among students were not really promoted. The findings of this study suggest that all eight factors should be trained to teachers. It is expected that when teachers practice those factors, student outcomes will be better.
\end{abstract}

Keywords: teacher instruction, the dynamic model, teacher improvement program

\section{Introduction}

It has been widely acknowledged that teachers play very important roles in any educational improvement (Creemers, 1994; Fullan, 2001; Harris, 2002; Harris \& Muijs, 2005; Marzano, 2007). However, not all teachers teach well. Research on reading comprehension has shown that teachers often test and assign comprehension questions but rarely teach their students the strategies (Kropiewnicki, 2006; Miller \& Perkins, 1989; Pressley, Wharton-McDonald, Hampston, \& Echevaria, 1998). Furthermore, Cooper (1986) states that much of the emphasis in helping students comprehend texts has been traditionally focused on what to do before reading and after reading, but not during reading.

Therefore, it is crucial to understand pedagogical actions that teachers should take to help students take charge of the process of constructing meaning from texts during reading. Moreover, these (academic) actions are the primary medium through which students make sense of instruction (Doyle, 1983). In this case, teacher effectiveness studies, which concern factors at the teacher level that promote student learning and better student outcome, can provide information on teacher pedagogical actions that lead to better student outcome.

In this paper, the dynamic model of educational effectiveness, especially at the classroom level (and thus is in the domain of teacher effectiveness studies), developed by Creemers and Kyriakides (2008) is used as the theoretical framework to understand teacher instructions in the classroom. The model consists of eight factors which are effective observable teacher behaviors: orientation, structuring, modeling, application, questioning, assessment, building classroom as a learning environment, and time management. These eight actors are theory-driven and have been previously found to be positively related to better student outcome, and therefore could be used as a reference in understanding teacher actions in the classroom and in designing a teacher improvement program. The findings of this study are expected to provide grounded foundation on how to develop a teacher improvement program and what to prioritize in the program.

\section{The Dynamic Model of Educational Effectiveness}

This section will review classroom factors that have been found to be related to better student learning outcome. The classroom factors in this case refer to teacher concrete actions in the classroom. This is due to the fact that compared to other factors such as teacher subject knowledge and teachers' teaching experience, teacher instruction in classrooms has been found to have stronger impact on student outcome. Therefore, this paper deals with the content that teachers teach and the way teachers deliver the content to their students. The content refers to curriculum planning, which for the case of Indonesia as the context of the study, is supposed to be developed by teachers themselves whereas the way teachers deliver their material is closely related to teacher concrete actions in classroom. 
Concerning the curriculum, the study focuses on reading comprehension in Junior Secondary Schools (JSS). In this case, the study concerns the process of teaching and learning of reading from the beginning till the end of the lesson. Regarding teacher instruction or actions in the classroom, as previously mentioned, the dynamic model of educational effectiveness (Creemers \& Kyriakides, 2008) is used as the framework. The model consists of four levels namely 1) context-level factors, which are the policies at the national level and their implementation; 2) school-level factors, which deals with the policies at the school level including their implementation; 3) classroom-level factors, which refer to teacher observable behavior at the classroom; 4) student-level factors, some of which are students' socio-economic status, gender, and subject motivation.

The model takes into account that the higher levels are expected to provide conditions for the operation of lower levels. Therefore, outcomes are provided by the combined effects of levels. However, as has been revealed by other studies (Antoniou, 2009; Creemers \& Reezigt, 1996), the model considers the classroom level as the most important factor. This section will discuss in detail about the classroom factors of the dynamic model, which are used as the framework to understand teachers' pedagogical actions defined in this research.

As can be seen in figure 1, the classroom level consists of eight factors: 1) orientation, structuring; 2) modeling; 3 ) application; 4) questioning; 5) assessment; 6) building classroom as a learning environment; 7) time management; and 8 ) assessment. The model is used since it can encourage not only during reading activities, but also pre and post reading activities. Orientation and structuring, which are the provision of objectives and explanation on what students are going to do and learn, could be considered as pre-reading activities.

Modeling is the provision of learning strategies for what students are going to learn and application is dealing with the opportunity for the students to apply the strategies they have learned. Therefore, both can be considered as during reading activities. It should be emphasized that the model promotes the use of problem solving technique in order to support self-regulated learning through modeling. Questioning is also underlined not only during reading but also in pre and post reading. It is suggested that teachers raise both product and process questions: product questions are related with explicit information mentioned in the text, whereas process questions will require students to go beyond the printed information. Questioning can take place throughout the lesson and therefore can serve as pre reading, during reading and post reading activities.

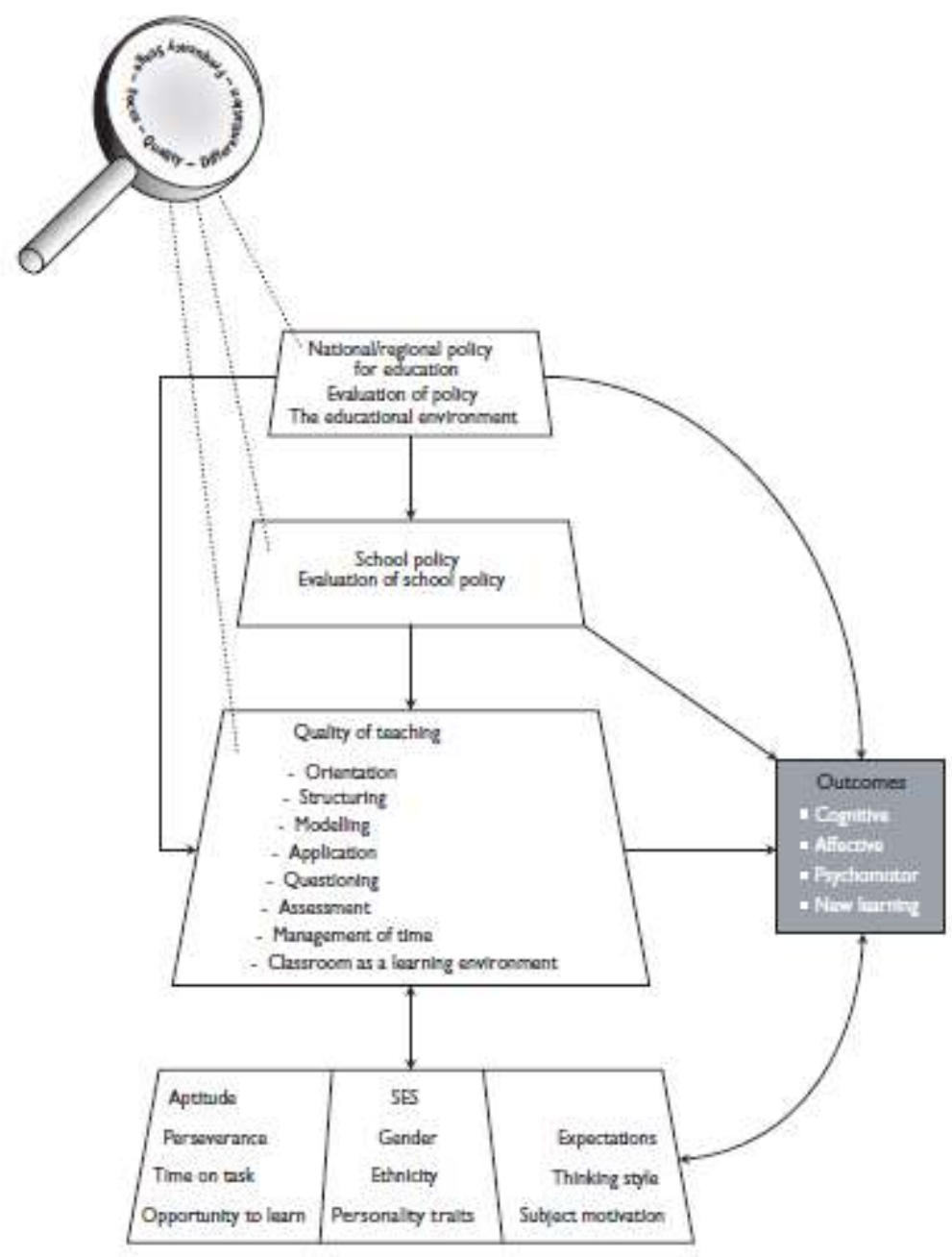

Figure 1. The Dynamic Model of Educational Effectiveness (Creemers \& Kyriakides, 2008)

Building classroom as a learning environment is dealing with teacher - student interactions and student-student interactions, teachers' roles in promoting cooperation and competition among students. Next, management of time is 
important to maximize students' engagement and make sure that they are on tasks throughout the lesson. Finally, assessment should enable teacher to gather data on their students' attainment as well as to use the data as a reflection to improve their teaching, which could serve as post reading activities.

Figure 1 also shows there are five dimensions that can be used to measure each factor, i.e. frequency, focus, stage, quality, and differentiation. Frequency refers to the quantity of each of the above classroom factors presented by the teacher. Focus deals with the specificity of the activity; whether an activity is too specific or too general in relation to the goals of the activity. Stage concerns the period at which an activity takes place and quality questions whether the activity is clear and understandable for students. Finally, differentiation refers to the extent to which activities associated with the above classroom factors are implemented in the same way for all groups of students. It is expected that teachers adapt specific needs of students and provide differentiated instruction according to individual student learning needs.

The following table attempts to describe practical and observable behaviors that teachers are supposed to do according to the above factors and dimensions especially in reading comprehension class.

Table 1. Classroom Factors of the Dynamic Model and Their Observable Behaviors in the Classroom especially for Reading Comprehension Class

\begin{tabular}{l} 
Classroom Factors \\
\hline ORIENTATION \\
1. Teachers are able to present or invite students to present the aims/goals of \\
learning (studying certain topic/theme, type of text and specific reading \\
skills) \\
2. When presenting the aims, teachers are able to: \\
a. Link the day's lesson to previous lesson or students' daily life. \\
b. Present the aims in different stages in accordance with the flow of the \\
c. Present clear and understandable aims for students. \\
d. Provide different ways of presenting the aims as a respond to different \\
background of students.
\end{tabular}

\section{STRUCTURING}

1. Teachers are able to present the structure of the lesson, which should include:

1. Topic

2. Type of text

3. Specific reading skills

4. Series of activities students will do

2. Teachers are able to explain the link among different activities

3. Teachers are able to signal the transition between one phase/activity and others

4. Teachers are able to provide clear and understandable structure of the lesson.

5. Teachers are able to provide different types of structuring due to different learning needs of students.

MODELING 1. Teachers are able to present the strategies of learning (specific reading skills planned to be taught). It is also possible for teachers to invite students to present the strategies.

2. Teachers are able to engage students in developing or demonstrating the strategies.

3. Teachers are able to provide clear and understandable strategies or modeling activity.

4. Teachers are able to provide different types of modeling activity to meet different learning needs of students.

APPLICATION 1. Teachers are able to provide tasks or exercises of each specific reading skill planned to apply the strategies presented during modeling.

2. When developing the tasks, teachers are supposed to consider:

1. Whether the text used in modeling stage should be different from the text used in application activities.

2. Whether the text used in application activities should be more difficult than the text used in modeling.

3. Whether different texts should be distributed to different groups of student

4. Whether different groups of students should be given different lengths of time to do the tasks 
1. Teachers are able to provide questions throughout the lesson in order to achieve the goals. The questions can address the specific reading skills planned to be taught or something from the previous lesson.

2. Teachers are able to provide both process and product questions.

3. Teachers are able to provide appropriate reaction if no answer is given by students.

4. Teachers are able to provide positive and constructive comments or feedback to students.

ASSESSMENT
1. Teachers are able to develop strategies to assess students' outcomes during
the day's lesson (formative assessment).
2. Teachers are able to develop questions or tasks in accordance to the
strategies to asses what students have understood from the day's lesson.
3. Teachers are able to decide when to deliver assessment.
4. Teachers are able to use different technique to gather data on student
outcomes.

CREATING CLASSROOM AS A LEARNING ENVIRONMENT

It should be noted that the last point in each of the above factors is dealing with differentiation dimension, which has been widely recognized as a difficult teaching skill. At the same time, this also means that these observable behaviors can show stages of teaching skills, which can serve as a very important foundation in designing the differentiated teacher improvement program in order to meet different needs of improvement for different groups of teachers. A study in Cyprus has used the Rasch model to identify the degree of difficulty of each teaching skill representing the classroom factors and their dimensions and the result shows that teaching skills can be grouped into five different stages (Kyriakides, Creemers, Antoniou, 2009). In this research, all factors and simplified dimensions as described in table 1 are used to understand teacher pedagogical actions in the reading comprehension class.

\section{Methods}

\subsection{Participants}

The study was conducted in 11 private madrasah Tsanawiyah (MTs) in Tangerang (6 schools) and South Jakarta (5 schools). MTs is an Islamic type of Junior High School, which students are aged 12/13 up to 14/15 years old. The schools are selected based on their willingness to join the study. Information and invitation to participate in the study was previously sent to the principals of private MTs in Tangerang and South Jakarta, Indonesia. The first 11 schools confirming their willingness were selected as the cases reported in this paper. In this study, one school was represented by 1 English teacher and hence 11 English teachers participated in the study.

Lower secondary schools were selected as a considerable number of studies have been done in primary schools (Scheerens, 2004). Senior Secondary School was not selected as beginning in the second year students are supposed to choose one major and this could be considerably complicated. Furthermore, madrasah was selected because of several reasons. The first was the fact that the quality of madrasah in general is lower as indicated by the minumum acknowledgement of its graduates from institutions under MONE (CEQDA, 2007). In addition, it is also reported that more than $80 \%$ of madrasahs are private with low quality of human resources and limited funds, which are assumed to affect the low quality of their teaching and learning process (CEQDA, ibid). With regards to the subject, as previously mentioned, reading comprehension was selected due to the fact that the national exam focuses merely on reading comprehension. 


\subsection{Procedure}

Instrumental case study (Stake, 1994) was used as an approach to understand particular cases to gain insight into an issue or theory. In this case, it was intended to understand teacher instruction in the classroom in order to develop an appropriate teacher improvement program. This is in line with what Cohen, Manion, \& Morrison (2000) state that case studies are a step in action; the information gathered may be interpreted and used for staff or individual selfdevelopment, formative evaluation, and in educational policy making.

Structured classroom observation instruments developed based on the above factors were modified for English especially for the teaching of reading comprehension as the focus of the study. Both low inference instrument and high inference instruments were used. The low inference instruments enable the observers to note what happen in the classroom. The high inference instrument, which is supposed to be filled in after the observation, requires the observer to rate a Likert-scale instrument to indicate the frequency of observed activities. Hence, the low inference instrument is expected to help the observers to fill in the high inference instrument. No reliability analysis was performed to the modified instrument due to the small number of participants. The pilot study was previously performed in order to adjust the instrument to the context of Indonesia and the specific subject involved in the study. Only one observer did the observation, yet she was previously trained in using the instrument.

\section{Results and Discussion}

This section reports the classroom observation descriptively by presenting what teachers did in their classrooms when delivering teaching and learning processes in relation to the eight classroom factors of the dynamic model. In the beginning, teachers spent more or less 10 minutes for introductory activities, i.e. greetings, checking students' attendance, asking if students had homework as well as introducing the observer. Some of them checked their students' attendance by calling all students' names and some by asking those who were absent. However, many of them were late (for about 10 minutes out of 60 minutes), and consequently the teaching and learning process was reduced. Studies on teacher coming late is rarely found, yet a large scale and comprehensive study (involving more than 8000 teachers) on teacher absenteeism in Indonesia reveals that overall, around one in ten teachers is found to be absent from school (Philip, et al., 2014).

The next 10 - 15 minutes were spent to discuss the homework or to review the previous lesson when there was no homework. However, teachers in general did not connect the day's lesson with the previous lesson nor students' daily life when they introduced a new topic. In addition, teachers did not explain the competencies that students were expected to accomplish during the day's lesson. No explanation on the series of activities students were going to do was provided. Teachers normally asked students to open their book to a certain page and briefly explained the topic they were going to learn on that day. Related to this study, in his dissertation, Utomo (2005) observes that most teachers only cover one topic in their lessons and no links are made with previous lessons, daily life situations or other subject domains. In other words, teachers did not provide enough orientation and structuring activities to facilitate students' awareness on the importance of the lesson and to monitor their activities. Hence, pre-reading activities were not well delivered.

The activities that followed were limited to reading aloud, translating the text and answering questions provided in the text. The questions were limited to product questions, answers of which were normally easy to find in the texts. There were no process questions, ones which required students to think beyond the printed information in the texts. In addition, teachers were generally text-book oriented; almost no questions were created by teachers themselves and none of the teachers introduced different passages other than the passages provided in the books. Concerning this text-book oriented approach, unfortunately, not all Indonesian textbooks provide good guidance and materials for teaching. Priyanto (2009) on his critical review of two English course books, for instance, concludes that the books did not give clear point on the fact that language is the realization of a social process that always has a social purpose. Instead, they tend to focus on form, without giving any further explanation on why and for what purposes learners should use those forms.

Next, concerning the modeling activities, teachers provided only little strategies for students to help them answer the questions. Nevertheless, this was in line with the types of questions raised during the teaching and learning where no process questions were raised. Some examples of product questions normally provided in the text book were WH (where, when, what, who) types of questions, which do not really require teachers to provide strategies for students in order to accomplish the work. Meanwhile, some examples of process questions include the questions to find the main ideas, to infer, or to summarize and to conclude. These types of questions could be considered as higher order thinking skills, which require students to think in a more critical way. Thus, the modeling and the application activities, which could serve as during reading activities, were minimal. Thus, this finding supports an old research conducted by Cooper (1986), which reported that the emphasis in reading comprehension class was much more on before reading and after reading, but not during reading. Questioning which took place in both during and post reading activities did happen, yet was limited to product questions only.

Furthermore, in conducting the teaching and learning process, all the teachers used whole-class instructions, where no student grouping was introduced. This finding was very common in Indonesian classroom, in which students were sitting in columns and rows and listening to teachers standing in front of their class or even sitting on their own desk. Similaly, Utomo (2005) explains that the classrooms are characterized by a didactic, whole-class style of teaching. In this situation, collaboration and competition among students was not really promoted by teachers. 
In summary, teachers in general had not yet practiced teacher instructional behaviors that have been found to be associated with better student outcome as indicated in the classroom factors of the dynamic model. Orientation activities were almost not provided at all whereas structuring was limited to teacher instructions like asking students to open certain pages of the book and asking for explanations about the topic. No further information on the competencies and series of activities during the lesson were provided. This is likely the reasons why many students are not aware of the importance of the lessons and do not really know in advance the series of activities they are going to learn. In addition, modeling was not really provided either, which was in line with the limited amount and types of application activities. Teachers only raised questions mentioned in the textbooks, which covered only product-based questions. Furthermore, teachers seemed to fail to manage their time well and did not arrange the classroom environment in such away to enable students to cooperate and to compete to each other. Finally, because most teachers were late and spent quite a long time for unnecessary introductory activities, students did not have maximum opportunity to learn.

The above findings have shown that teacher did not really practice the principles of effective teaching as described in the classroom factors of the dynamic model. These findings are not very surprising. Several researchers have identified some ineffective practices of Indonesian teachers. As previously mentioned, Utomo (2005) for instance recognizes that it is very common to see a didactic, whole-class style of teaching, in most Indonesian classrooms, in which teachers pay only little attention to the children's needs as individual learners. In addition, Utomo (ibid) also notices that in one lesson, only one topic is covered and no links are made with previous lessons, daily life situations or other subject domains. Similarly, Kaluge, Setiasih, and Tjahjono (2004) argue that teachers in general are not able to create an active, joyful and effective learning environment.

Moreover, it is also quite common to see teachers in Indonesia take a safer approach to teaching to the test to prepare the national exam. Hendayana (2007) reports that instruction and learning have been primarily centered around test preparation. However, it should be noted that this is also common in other countries which establish education standards where teachers are to facilitate all students regardless their background to achieve the minimum competence required in the standards (Doherty, 2001; Hunt, Jr., Rizzo, \& White, 2009; Proefriedt, 2008; Richman, 2001; Wise \& DarlingHammond, 1983)

Furthermore, the Indonesian government has launched several programs to improve teachers' teaching quality, the most current of which is teacher certification program. A study conducted by the World Bank (2012) reports that the number of teachers finishing their bachelor degree has increased significantly due to the inclusion of a degree in the certification criteria. However, the results of subject matter tests indicate that teachers in general are not qualified yet and those who have earned bachelor degree score only marginally better. Worse than this, the same study concludes that certified teachers do not imply that they are better teachers as seen from student learning gains. In other words, the certification program has not yet resulted in the improvement of teachers' subject knowledge and teachers' teaching quality.

\section{Conclusion: What to Prioritize in Teacher Improvement Programs?}

The results of this study as well as those of the World Bank (2012) provide a strong indication that necessary actions should be taken in order to improve teachers' teaching quality. Teachers' teaching quality in this case refers to teacher behavior in the classroom as previously noted in the theoretical framework of this paper. The findings of this study show that teachers did not yet practice the principles of effective teaching as described in the classroom factors of the dynamic model. Therefore, it is suggested that teacher improvement programs are created in order to assist teachers improve their teaching quality to be better teachers.

In developing a teacher improvement program, the most fundamental question is what should be prioritized or what should be delivered in the training sessions so that teaching instruction could be improved. In this case, the classroom factors of the dynamic model could be used as a reference in deciding what to be improved. Because the results of this study indicate that all eight factors of the dynamic model are rarely practiced by teachers, it is necessary for teachers to improve their teaching practice in all classroom factors suggested by the dynamic model. There are eight factors in the model, which are based on previous research findings on teacher effectiveness.

Concerning orientation, teachers need to link what students are going to learn with either the previous lessons or the student's daily life, which is expected to raise student motivation and student awareness on the importance of the lesson. Next, it is advised that teachers inform students about what they are going to do and what they should accomplish at the end of the lesson (structuring activities) so that they understand in advance the series of activities they are going to do during the lesson. In this way, pre-reading activities are well fulfilled. In addition, in during reading activities, in order for students to know the strategies of learning, teachers are expected to equip students with the necessary strategies, which are at the same time also expected to promote self-regulated learning. When they understand the learning strategies, they could use the strategies to learn outside the classroom. Furthermore, teachers need to provide application activities, which are immediate exercises as learning opportunities for students to practice the learning strategies. With respect to questioning, which can take place from the beginning till the end of the lesson, teachers need to combine both product and process questions in order to promote higher order thinking skills. Furthermore, when necessary, it is also good when teachers vary the learning environment by for instance grouping students according to certain criteria such as student ability, student learning style and so on.

In short, when the teacher development program is designed, the eight classroom factors of the dynamic model could be used as a reference on what aspect need to be improved. Moreover, these eight classroom factors could serve as prereading, during reading and post reading activities, which have been commonly known strategies in the teaching of 
reading comprehension. The findings of this study imply that all eight factors of the dynamic model should be introduced and trained to teachers. Because these factors have been previously found to be associated with better student achievement, it is expected that when teachers are able to practice them in their classroom activities, their teaching quality will improve and eventually student achievement will also improve.

\section{References}

Antoniou, P. (2009). Using the dynamic model of educational effectiveness to improve teaching practice: building an evaluation model to test the impact of teacher professional development programs. Unpublished $\mathrm{PhD}$ thesis. University of Cyprus: Department of Education.

CEQDA (2007). Laporan dampak kebijakan akreditasi, BOS, dan sertifikasi terhadap masa depan madrasah di DKI Jakarta. Jakarta: Kerjasama LAPIS dan CEQDA UIN Jakarta.

Cohen, L., and Manion, L., \& Morrison, K., (2000) (5 ${ }^{\text {th }}$ Edition), Research Methods in Education, London: Routledge

Falmer.

Cooper, J.D. (1986). Improving Reading comprehension. Boston: Houghton Mifflin Co.

Creemers, B.P.M. (1994). The Effective Classroom. London: Cassel.

Creemers, B.P.M. and Kyriakides, L. (2008). The Dynamics of Educational Effectiveness. London: Routledge.

Creemers B.P.M., \& Reezigt G.J. (1996). School level conditions affecting the effectiveness of instruction. School Effectiveness and School Improvement, 7(3), 197-228.

Doherty, K.M. (2001, January 11). Poll: Teachers support standards with hesitation. Education Week / Quality Counts, 20(17).

Doyle, W. (1983). Academic Work. Review of Educational Research, 53, 159-199.

Fullan, M. (2001). The new meaning of educational change. London: Routledge Falmer.

Harris, A. (2002). School Improvement: what's in it for school?. London: Falmer Press.

Harris, A. \& Muijs, D. (2005). Improving schools through teacher leadership. London: Open University Press.

Hunt Jr., J.B, Rizzo, J.A, \& White, A.D. (2009). Realizing the promise of standards-based reform. The Hunt Institute's BLUEPRINT for Education Leadership No. 3. Retrieved from http://www.huntinstitute.org/elements/media/files/Blueprint-Number-3-June-2009.pdf.

Kaluge, L., Setiasih, Tjahjono, H. (2004). The Quality Improvement of Primary Children Learning through a SchoolBased Programme in Indonesia. A Research Paper. East Java: Universitas Surabaya.

Kropiewnicki, M. (2006). An investigation of effective instructional methods to train preservice teachers in reading comprehension strategies. Paper presented for the 2006 annual meeting of the American Educational Research Association "Education Research in the Public Interest" at San Fransisco.

Kyriakides, L., Creemers, B.P.M. \& Antoniou, P. (2009). Teacher behaviour and student outcomes: Suggestions for research on teacher training and professional development. Teaching and Teacher Education, 25 (1), 12-23.

Marzano, R.J. (2007). The art and science of teaching. Alexandria, VA: Association for Supervision and Curriculum Development.

McKenzie, P., Nugroho, D., Ozolins, C., McMillan, J., Sumarto, S., Toyamah, N., Febriany, V., Sodo, R. J., Bima, L., \& Sim, A. A. (2014). Study on Teacher Absenteeism in Indonesia 2014. Jakarta : Education Sector Analytical and Capacity Development Partnership (ACDP).Miller, L.D. \& Perkins, K. (1989). ESL reading comprehension institution. (ERIC Document Reproduction Services No. ED303779).

Pressley, M., Wharton-McDonald, R., Hampston, J. M., \& Echevarria, M. (1998). The nature of literacy instruction in ten grade 4 and 5 classrooms in upstate New York. Scientific Studies of Reading, 2, 159-191.

Priyanto, A.D. (2009). Maximizing SFL Contriburion to ELT Indonesia. UAD TEFL Conference. Yogyakarta: UAD

Press.

Proefriedt, W.A. (2008). High expectations: The cultural roots of standards reform in American Education. New York, NY: Teachers College Press.

Richman, S. (2001). Parent power: why national standards won't improve education. Policy analysis no. 396. Washington, DC.: Cato Institute.

Scheerens, J. (2004). Review of school and instructional effectiveness research. Paper commissioned for the EFA Global Monitoring Report 2005, The Quality Imperative. Retrieved online from http://www.mecd.gob.es/dctm/cee/encuentros/effectiveteachingscheerens.pdf?documentId=0901e72b815f9784.

Stake, RE. (1994). Case Studies. In NK Denzin \& YS Lincoln (Eds.) Handbook of Qualitative Research (pp. 236-247). Thousand Oaks, Sage Publications.

The World Bank. (2012). Teacher certification in Indonesia: a doubling of pay or a way to improve learning. A Policy Brief No. 73264.

Utomo, E. (2005). Challenges of Curriculum Reform in the Context of Decentralization: The Response of Teachers to Competency Based Curriculum (CBC) and Its Implementation in Schools, unpublished doctoral dissertation, University of Pittsburgh.

Wise, A. E. \& Darling-Hammond, L (1983). Beyond standardization: State standards and school improvement. Washington, DC: Dingle Associates, Inc. 